\title{
FORECASTING THE POPULATION OF RETIREMENT AGE IN RURAL RUSSIA
}

Tatiana BLINOVA, Laboratory of Social Development of Agro-Industrial Complex and Rural Areas, Institute of Agrarian Problems of the Russian Academy of Sciences, Moskovskaya 94, Saratov, 410012, Russian Federation, ruandre@ mail.ru (corresponding author) Svetlana BYLINA, Laboratory of Social Development of Agro-Industrial Complex and Rural Areas, Institute of Agrarian Problems of the Russian Academy of Sciences, Moskovskaya 94, Saratov, 410012, Russian Federation, svbylina@ rambler.ru

Population aging and an increase in the number of older age cohorts are demographic constraints and barriers to sustainable rural development. Rural areas of Russia have been affected by demographic aging to a greater extent than urban areas; the proportion of the population of retirement age in rural areas is higher than in urban areas. The purpose of the study is a forecasting the rural population of retirement age and changes in the demographic load in Russia. To construct a demographic forecast, the component method was used. The results show that the number of rural population of retirement age in 2020-2029 will decrease by $4.2-7.3 \%$ with zero migration and 5.8-8.9\% taking into account the scale of rural-urban migration. From 2034, an increase in the number of persons of retirement age is projected. In 2020-2049 the number of rural pensioners will grow in the medium and high scenarios of demographic development by $4.4-5.5 \%$, excluding migration. The article calculates coefficient of demographic load. The analysis shows that the rural population $0-15$ years old is steadily declining. At the same time the number of persons of retirement age in Russia is steadily increasing, both in rural and urban areas. The decline in the birth rate has led to a decrease the demographic load coefficient by children and an increase of the old-age dependency ratio. Upcoming demographic changes must be taken into account in the strategic planning and development of regional programs.

Keywords: rural population of retirement age, forecast, Russian Federation.

\section{INTRODUCTION}

The population of Russia in 2020 decreased by more than 0.5 million and as of January 1, 2021, it was 146.2 million (Rosstat, 2021). The main reason is the high natural population decline, which was only partially compensated by the migration gain. Simultaneously with the increase in the death rate, which during the COVID-19 pandemic reached its maximum value in the last 10 years, the birth rate decreased, and the natural population decline increased. In January 2021, compared with January 2020, a decrease in the number of births occurred in 80 regions of the Russian Federation, and an increase in the number of deaths in 84 . The number of people infected with the COVID-19 coronavirus amounted to more than 7.0 million people, of which 6.3 million recovered, more than 188 thousand people died (Rosstat, 2021). By January 2021, the number of deaths from all classes of causes of death exceeded the number of births by 2.1 times; natural population growth was recorded only in 9 regions of Russia (Rosstat, 2021). The rural population decreased and as of January 1, 2021 amounted to 36.9 million people (Rosstat, 2021). Every fourth resident of the country lives in rural areas, and the share of the rural population is $25.2 \%$ (2021). At the same time, in such regions of Russia as the Republic of Dagestan, the Republic of Altai, the Republic of Kalmykia, the Republic of Adygea, the Chechen Republic, the KarachayCherkess Republic from 50 to $70 \%$ of citizens live in rural areas. Demographic constraints are a barrier to sustainable bioeconomy and rural development. Unfavorable demographic trends in the development of rural areas, including aging, decrease of the working-age population, decline in the birth rate, reduction in the number of women of fertile age, increase the demographic load, actualize the assessment of promising changes.

In addition to the natural population decline, the regions of Russia are aging, and the proportion of elderly people is increasing. Researchers believe that currently in Russia "there is an increase in the rate of population ageing which the countries of Western, Central and Southern Europe (Spain, Portugal, Greece and Italy) experienced in the 1970s and 1980s, and the Baltic States (like the rest of Eastern Europe) - in the 1980s and 1990s" (Petrosian et al., p. 46). Population aging having a negative impact on economic growth, the national labor market, and the pension system (Kim, Hewings, 2013; Kudo et al., 2015; Lin et al., 2018; Lee, Petrosian et al, 2019; Shin, 2019; Blinova, 2021). "The most significant consequence of an aging population is the ever-increasing load on the able-bodied population, and primarily due to the load from above (due to with an increase in the proportion of the elderly), while the load from below (children) is gradually decreasing due to a decrease in the birth rate in almost all developed countries" (Karpova, Proklova, 2020, p. 53).

Copyright (C) 2021 The Authors. Published by Vytautas Magnus University. This is an open-access article distributed under the terms of the Creative Commons Attribution License (CC BY 4.0), which permits unrestricted use, distribution, and reproduction in any medium, provided the original author and source are credited. 
Demographic aging is a challenge for the economies of most countries of the world, adapting to which, society increases the retirement age. In Russia the pension reform started in 2019, when the Federal law No. 350 (2018) was adopted. According to this law, by 2028, it will be a gradual increase in the retirement age for men - up to 65 years (from 60), for women - up to 60 years (from 55). Population aging and an increase in the number of older age cohorts are demographic constraints and barriers to sustainable rural development. Rural areas of Russia have been affected by demographic aging to a greater extent than urban areas; the proportion of the population of retirement age in rural areas is higher than in urban areas.

The object of the research is the rural population of retirement age. The purpose of the study is a forecasting the rural population of retirement age and changes in the demographic load in Russia. To achieve this aim, the tasks of theoretical analysis of the patterns of aging were solved, and the assessment of the impact of the pension reform in Russia on changes in the population of retirement age and demographic load.

\section{MATERIAL AND METHODS}

Methods for predicting the size and structure of the population of the countries of the world are widely known (Rowland, 2003; Alho, Spencer, 2005; Alho et al., 2006). To construct a demographic forecast, the component method was used. This method has been tested previously (Blinova et al., 2020). Scenarios of demographic development of rural areas in 2029-2049 are described: Baseline, Medium, High, Baseline with migration, Medium with migration, High with migration. The database was formed on the basis of statistics presented on the official website of Federal State Statistics Service - Rosstat (Rosstat, 2002; Rosstat, 2007; Rosstat, 2012; Rosstat, 2015; Rosstat, 2017; Rosstat, 2019; Rosstat, 2020, Rosstat, 2021). The calculations were performed using Mathcad 14.0. The baseline scenario is based on the assumption that the age-specific fertility of rural population remain unchanged throughout the forecast period (until January 1, 2049). The medium scenario was developed on the basis of the expected birth rate increase at the age of 15-19 years and over 35 years old until 2028, the prevailing trends in rural mortality rates are extrapolated up to 2028. A high forecast scenario can be called normative, because it is based on the targets presented in the National Project "Demography" (2019). When assessing the results of migration, Rosstat data were used, and also the patterns and trends in the scale of rural-urban migration during the Covid-19 pandemic were taken into account (Mkrtchyan, 2019; Blinova et al, 2020). The forecast for the population of retirement age took into account the specifics of the pension reform in Russia.

\section{RESULTS AND DISCUSSION}

\section{Forecast of the rural population at retirement age}

As a result of the aging of the population, the number and proportion of people of retirement age is increasing. Table 1 shows the dynamics of the rural and urban population of retirement age in Russia.

Table 1. Population at retirement age in Russian Federation, 2015-2020, thousand people

\begin{tabular}{|l|l|l|l|l|l|l|}
\hline Population at retirement age & 2015 & 2016 & 2017 & 2018 & 2019 & 2020 \\
\hline Rural population & 9242.2 & 9459.3 & 9647.6 & 9827.4 & 10005.1 & 9629.5 \\
Urban population & 25921.2 & 26527.0 & 27037.5 & 27535.2 & 27983.9 & 26999.0 \\
Total population & 35163.4 & 35986.3 & 36685.1 & 37362.6 & 37989.0 & 36628.5 \\
\hline
\end{tabular}

Source: Rosstat data $(2017 ; 2019 ; 2021)$

As the data in the table show in 2015-2019 the number of pensioners in Russia increased by $8 \%$, while the number of rural pensioners increased by $8.3 \%$. The growth rate of rural pensioners is higher than that of urban ones. In 2019-2020 an increase in the retirement age during the pension reform in Russia, as well as an increase in mortality during the Covid19 pandemic, led to a decrease in their number in rural areas by $3.8 \%$, in the city - by $3.5 \%$.

The forecast of the rural population of retirement age (2029-2049) is presented in Table 2.

Table 2. Rural population of retirement age, 2020-2049, thousand people (women aged over 60; men aged over 65)

\begin{tabular}{|l|l|l|l|l|l|l|}
\hline Scenarios & 2020 & 2029 & 2034 & 2039 & 2044 & 2049 \\
\hline Baseline & 9630 & 8931 & 9039 & 8949 & 8704 & 8496 \\
Medium & 9630 & 9230 & 9771 & 10010 & 10069 & 10055 \\
High & 9630 & 9197 & 9791 & 10036 & 10170 & 10160 \\
Baseline with migration & 9630 & 8777 & 8792 & 8617 & 8296 & 8022 \\
Medium with migration & 9630 & 9073 & 9511 & 9673 & 9607 & 9504 \\
High with migration & 9630 & 9044 & 9533 & 9736 & 9705 & 9623 \\
\hline
\end{tabular}

Source: own calculations based on Rosstat data $(2002 ; 2007 ; 2012 ; 2015 ; 2017 ; 2019 ; 2021)$

The data show that the number of rural population of retirement age in 2020-2029 will decrease by 4.2-7.3\% with zero migration and 5.8-8.9\% taking into account the scale of rural-urban migration. From 2034, an increase in the number of persons of retirement age is projected. In 2020-2049 the number of rural pensioners will grow in the medium and high scenarios of demographic development by $4.4-5.5 \%$, excluding migration.

\section{Forecast of the rural population below the working age}

As the data show (table 3), the number of the rural population of Russia below the working age will decrease until 2039 according to all alternative scenarios of demographic development, except for the «High» one. 
Table 3. Rural population below the working age (0-15), 2020-2049, thousand people

\begin{tabular}{|l|l|l|l|l|l|l|}
\hline Scenarios & 2020 & 2029 & 2034 & 2039 & 2044 & 2049 \\
\hline Baseline & 7414 & 5958 & 5204 & 5091 & 5203 & 5207 \\
Medium & 7414 & 5978 & 5255 & 5175 & 5302 & 5307 \\
High & 7414 & 6236 & 5820 & 6052 & 6286 & 6320 \\
Baseline with migration & 7414 & 5831 & 5039 & 4900 & 4971 & 4923 \\
Medium with migration & 7414 & 5856 & 5096 & 4989 & 5067 & 5018 \\
High with migration & 7414 & 6106 & 5644 & 5836 & 6008 & 5977 \\
\hline
\end{tabular}

Source: own calculations based on Rosstat data $(2002 ; 2007 ; 2012 ; 2015 ; 2017 ; 2019 ; 2021)$

Then, a gradual increase in the size of this age group is predicted. The current migration dynamics may have a negative impact on the rural population under the age of less than the able-bodied population in the period from 2044 to 2049.

Predicted shifts in the age group of rural population will inevitably affect the size of the demographic load on the working-age population.

\section{Forecast of demographic load coefficient}

In the papers of Russian authors, three types of demographic load coefficient are discussed, firstly, the demographic load by children (the number of people $0-15$ years old per 1000 people of working age), secondly, the demographic load by the elderly (the number of people of retirement age per 1000 people of working age), in - third, the general demographic load (the number of persons 0-15 years old plus the number of persons of retirement age per 1000 persons of working age) (Karpova, Proklova, 2020). The article calculates coefficient of general demographic load. The analysis shows that the rural population 0-15 years old is steadily declining (Blinova et al, 2020). At the same time the number of persons of retirement age in Russia is steadily increasing, both in rural and urban areas. Lutz and other authors (2008) notes that the future paths of population ageing result from specific combinations of declining fertility and increasing life expectancies in different parts of the world. The decline in the birth rate has led to a decrease the demographic load coefficient by children and an increase of the coefficient of demographic load of the elderly.

In order to construct a forecast of the number of persons of retirement age and calculate the demographic load, it is necessary to know the stages of raising the retirement age until 2028 (Table 4).

Table 4. Scheme for increasing the retirement age in Russia in 2021-2028

\begin{tabular}{|l|l|l|l|l|}
\hline Years & Working age for men & Retirement age for men & Working age for women & Retirement age for women \\
\hline 2021 & $16-60$ years & 61 and over & $16-55$ years & 56 and over \\
2022 & $16-61$ years & 62 and over & $16-56$ years & 57 and over \\
2023 & $16-61$ years & 62 and over & $16-56$ years & 57 and over \\
2024 & $16-62$ years & 63 and over & $16-57$ years & 58 and over \\
2025 & $16-62$ years & 63 and over & $16-57$ years & 58 and over \\
2026 & $16-63$ years & 64 and over & $16-58$ years & 59 and over \\
2027 & $16-63$ years & 64 and over & $16-58$ years & 59 and over \\
2028 & $16-64$ years & 65 and over & $16-59$ years & 60 and over \\
\hline
\end{tabular}

Source: Rosstat data

The data in the table show that only from 2028 onwards, the retirement age is 65 years for men and 60 years for women.

The article calculates coefficient of general demographic load. The analysis shows that the rural population 0-15 years old is declining. At the same time the number of persons of retirement age in Russia is increasing, both in rural and urban areas. The decline in the birth rate has led to a decrease the demographic load coefficient by children and an increase of the coefficient of demographic load of the elderly.

Table 5. The demographic load on the working-age rural population, 2020-2049, people per 1000 working age (women aged 16-59; men aged 16-64)

\begin{tabular}{|l|l|l|l|l|l|l|}
\hline Scenarios & 2020 & 2029 & 2034 & 2039 & 2044 & 2049 \\
\hline Baseline & 898 & 712 & 693 & 712 & 744 & 778 \\
Medium & 898 & 725 & 725 & 759 & 807 & 852 \\
High & 898 & 734 & 752 & 804 & 854 & 889 \\
Baseline with migration & 898 & 712 & 692 & 713 & 745 & 780 \\
Medium with migration & 898 & 726 & 725 & 762 & 809 & 855 \\
High with migration & 898 & 735 & 752 & 809 & 856 & 893 \\
\hline
\end{tabular}

Source: own calculations based on Rosstat data $(2002 ; 2007 ; 2012 ; 2015 ; 2017 ; 2019 ; 2021)$ 
By 2029, a decrease in the level of the general demographic load is forecasted to be 16.9-19.5\% from the level of 2019 , and then it will gradually increase. These changes are explained by the influence of the pension reform, which resulted in a decrease in the population at retirement ages. By 2049, the demographic load will increase by $0.7 \%$ from the level of 2019 only in the optimistic scenario, in all other scenarios it is expected a decrease to $88-96.5 \%$ relative to the data in 2019.

\section{Forecast of old-age dependency ratio}

As the data in the table show, in 2020-2049 old-age dependency ratio will increase by $32.6 \%-54.3 \%$. After declining in $2020-2024$ by $0.3 \%-0.7 \%$ the old-age dependency ratio increases until $2039(17.5 \%-22.0 \%)$, and then the growth rate slows down.

Table 6. Old-age dependency ratio (persons over 65 years of age per 1 thousand persons of working age (women aged 16-59; men aged 16-64)

\begin{tabular}{|l|l|l|l|l|l|l|}
\hline Scenarios & 2020 & 2029 & 2034 & 2039 & 2044 & 2049 \\
\hline Baseline & 291 & 342 & 358 & 369 & 377 & 386 \\
Medium & 291 & 354 & 387 & 414 & 435 & 445 \\
High & 291 & 352 & 389 & 416 & 435 & 448 \\
Baseline with migration & 291 & 343 & 359 & 370 & 378 & 386 \\
Medium with migration & 291 & 355 & 388 & 415 & 435 & 446 \\
High with migration & 291 & 353 & 388 & 417 & 436 & 449 \\
\hline
\end{tabular}

Source: own calculations based on Rosstat data $(2002 ; 2007 ; 2012 ; 2015 ; 2017 ; 2019 ; 2021)$

The old age dependency ratio in Russia is lower than in other countries, such as Germany, Italy and so on, this is explained by the fact that different countries are at different stages of the demographic transition (Petrosian et al, 2019). An assessment "of the prospects of the pension burden shows only a temporary effect of raising the retirement age to solve the problem of imbalance in the joint pension system: an increase in the burden of pensioners after 2028 will be observed in almost the majority of regions» (Petrosian et al., p.67).

\section{CONCLUSION}

The paper presents a medium-term forecast and six alternative scenarios of the size of the rural population of retirement age up to 2049 in Russia. The research results led to the following conclusions.

The results show that the number of rural population of retirement age in 2020-2029 will decrease by 4.2-7.3\% with zero migration and 5.8-8.9\% taking into account the scale of rural-urban migration. From 2034, an increase in the number of persons of retirement age is projected. In 2020-2049 the number of rural pensioners will grow in the medium and high scenarios of demographic development by $4.4-5.5 \%$, excluding migration.

The rural population below the working age (0-15) will decline in 2020-2039 for all scenarios of demographic development, in 2039-2049 a gradual increase in the size of this age group is projected.

The demographic load on the working-age population initially decreases from 898 people per 1000 (2020) to 712734 people (2039), but subsequently increases to $778-889$ people (2049). programs.

Upcoming demographic changes must be taken into account in the strategic planning and development of regional

\section{REFERENCES}

1. Alho J., Alders M., Cruijsen H., Keilman N., Nikande, T., Pham D.Q. 2006. New forecast: Population decline postponed in Europe. Statistical Journal of the United Nations Economic Commission for Europe, Vol. 23(1), pp. 1-10. https://doi.org/10.3233/SJU2006-23101

2. Alho J., Spencer B. 2005. Statistical demography and forecasting. New York: Springer.

3. Blinova T. V., Bylina S. G., Rusanovskiy V. A. 2020. Forecasting Changes of Populations in Rural Areas of Russia. Scientific Articles. Moscow: Institute of Economic Forecasting Russian Academy of Sciences, pp. 466-482. https://doi.org/10.47711/2076318-2020-466-482

4. Blinova T. V. 2021. Demographic aging of rural areas of Russia. AIC: Economics, Management, Vol. 2, pp. 76-80. https://doi.org/10.33305/212-76 (in Russian)

5. Karpova O., Proklova T. 2020. Demographic load in Russia in the 2000-s. Bulletin of Semashko National Research Institute of public health, Vol. 1, pp. 51-57 (in Russian).

6. Kim T. J., Hewings G. J. D. 2013. Endogenous Growth in an Aging Economy: Evidence and Policy Measures. The Annals of Regional Science, Vol. 3, pp. 705-730. https://doi.org/10.1007/s00168-012-0527-z

7. Kudo S., Mutisya E., Nagao M. 2015. Population Aging: An Emerging Research Agenda for Sustainable Development. Social Sciences, Vol. 4, pp. 940-966. https://doi.org/10.3390/socsci4040940

8. Lee H.H., Shin K. 2019. Nonlinear effects of population aging on economic growth. Japan and the World Economy, Vol. 51 [100963]. https://doi.org/10.1016/j.japwor.2019.100963

9. Lin B., Lin Z., Zhang Y.Y., Liu W. 2018. The Impact of the New Rural Pension Scheme on Retirement Sustainability in China: Evidence of Regional Differences in Formal and Informal Labor Supply. Sustainability, Vol.10(12), 4366. https://doi.org/10.3390/su10124366 
10. Lutz W., Sanderson W., Scherbov S. 2008. The coming acceleration of global population ageing. Nature, Vol. 451, pp. 716-719. https://doi.org/10.1038/nature06516

11. Mkrtchyan N. 2019. Migration in rural areas of Russia: territorial differences. Population and Economics, Vol. 3(1), pp. 39-51. https://doi.org/10.3897/popecon.3.e34780

12. National project "Demography". Available at http://government.ru/rugovclassifier/839/events/

13. Petrosian A, Shevchuk E., Kirillov P., Mozgunov N. 2019. Geographical patterns of population aging in Russia. Demographic Review. English selection, pp. 45-69. https://doi.org/10.17323/demreview.v6i5.11460

14. Rosstat, 2002: Demographic yearbook of Russia. 2002. Available at https://rosstat.gov.ru/folder/210/document/ 13207

15. Rosstat, 2007: Demographic yearbook of Russia. 2007. Available at https://rosstat.gov.ru/folder/210/document/ 13207

16. Rosstat, 2012: Demographic yearbook of Russia. 2012. Available at https://rosstat.gov.ru/folder/210/document /13207

17. Rosstat, 2015: Demographic yearbook of Russia. 2015. Available at https://rosstat.gov.ru/folder/210/document/ 13207

18. Rosstat, 2017: Demographic yearbook of Russia. 2017. Available at https://rosstat.gov.ru/folder/210/document/ 13207

19. Rosstat, 2019: Demographic yearbook of Russia 2019. Available at https://rosstat.gov.ru/folder/210/document/ 13207

20. Rosstat, 2020: Information about the socio-economic situation in Russia, January, 2020. Available at https://rosstat.gov.ru/ storage/mediabank/oper-01-2020.pdf

21. Rostst, 2021: Information about the socio-economic situation in Russia, January, 2021. Available at https://rosstat.gov.ru/ storage/mediabank/OmnPvYUx/oper-01-21.pdf

22. Rosstat, 2021: Information about the socio-economic situation in Russia, January - February, 2021. Available at https://rosstat.gov.ru/storage/mediabank/cPP0b1Am/oper-02-21.pdf

23. Rowland, D. T. 2003. Demographic methods and concepts. Oxford: University Press.

24. The Federal law of October 3, 2018, No. 350. On amendments to certain legislative acts of the Russian Federation on granting and payment of pensions. Available at http://www.kremlin.ru/ acts/bank/43614 